DOI 10.22460/infinity.v6i1.233

\title{
ANALYSIS OF STUDENTS' MATHEMATICAL POWER IN TERMS OF STIFIN TEST
}

\author{
Isna Rafianti ${ }^{1}$, Heni Pujiastuti ${ }^{2}$ \\ ${ }^{1,2}$ Mathematics Education Sultan Ageng Tirtayasa University, Serang, Indonesia \\ ${ }^{1}$ isnarafianti@untirta.ac.id, ${ }^{2}$ henipujiastuti@untirta.ac.id
}

Received: December 18, 2016; Accepted: January 2, 2017

\begin{abstract}
This research is motivated by the poor performance of students in particular mathematical power. One reason is that learning tends to be centered on teachers who emphasize the procedural process, mechanistic task and less provide opportunities for students to develop the ability to think mathematically. In terms of learning, each individual has their advantages and disadvantages to absorb the lessons given. But in the world of education is now known various methods in order to meet the demands of individual differences, one of which is STIFIn to determine the dominance of machine intelligence to make students more comfortable in the learning process that is expected to enhance the mathematical power. This research approach is qualitative descriptive that seeks to analyze the characteristics of students' mathematical power in terms of STIFIn. This research was conducted in SMAN 2 Kota Serang, with research subjects are five students of eleven grade derived from each type STIFIn different categories according to STIFIn. Instruments in this study are mathematical power test and interview. The results showed that mathematical power of Thinking and Sensing type has higher than the other type, followed by the type Feeling, Intuiting and the last is the type of Instinct.
\end{abstract}

Keywords: mathematical power, STIFIn

\begin{abstract}
Abstrak
Penelitian ini dilatarbelakangi oleh rendahnya prestasi siswa terutama dalam penguasaan matematika. Salah satu alasannya adalah bahwa pembelajaran cenderung berpusat pada guru yang menekankan proses prosedural, tugas mekanistik dan kurang memberikan kesempatan bagi siswa untuk mengembangkan kemampuan berpikir matematis. Dalam hal belajar, setiap individu memiliki kelebihan dan kekurangan mereka untuk menyerap pelajaran yang diberikan. Namun, dalam dunia pendidikan saat ini sudah dikenal berbagai metode untuk memenuhi tuntutan perbedaan individu, salah satunya adalah STIFIn yaitu metode untuk menentukan dominasi kecerdasan mesin untuk membuat siswa lebih nyaman dalam proses pembelajaran sehingga diharapkan dapat meningkatkan daya matematis siswa. Pendekatan penelitian ini adalah deskriptif kualitatif yang bertujuan untuk menganalisis karakteristik daya matematis siswa ditinjau dari tes STIFIn. Penelitian ini dilakukan di SMAN 2 Kota Serang, dengan subjek penelitian adalah lima siswa dari sebelas kelas yang berasal dari masing-masing jenis STIFIn kategori yang berbeda sesuai dengan STIFIn. Instrumen dalam penelitian ini adalah tes daya matematis siswa dan wawancara. Hasil penelitian menunjukkan bahwa daya matematis tipe Thinking dan Sensing memiliki skor yang lebih tinggi daripada tipe lainnya, kemudian diikuti oleh tipe Feeling, Intuiting dan yang terakhir adalah tipe Instinct.
\end{abstract}

Kata Kunci: daya matematis, STIFIn

How to Cite: Rafianti, I. \& Pujiastuti, H. (2017). Analysis of Students' Mathematical Power in Terms of Stifin Test. Infinity, 6 (1), 29-36. 


\section{INTRODUCTION}

National Council of Teachers of Mathematics (2000) stated, the purpose of learning mathematics is to develop: the ability to explore, construct a conjecture; and arrange reason logically, non-routine problem solving skills; the ability to communicate mathematically and use mathematics as a tool of communication, the ability to connect between mathematical ideas and between mathematics and other intellectual activity. Abilities in the learning objectives referred to mathematical power (mathematical power) or math skills (doing math).

Japar (2015) stated that the results of previous studies show low achievement of students for subjects, especially mathematics students' mathematical power, namely: (1) understanding the concept 41.73; (2) the mathematical reasoning 40.79; (3) Troubleshooting 17.31; (4) The mathematical connection 26.35; and (5) mathematical communication 40.32. At this time, students' mathematical power has not been fully achieved. According Suwarsono (Suradi, 2006: 9) difficulties experienced by students in studying mathematics is inseparable from teaching strategies that have been used in schools, the teaching strategies classical with the lecture method as the primary method. The learning which tends to be centered on teachers who emphasize the procedural process, the task of training the mechanistic and less provide opportunities for students to develop the ability to think mathematically (Djohar, 2003, IMSTEP-JICA, 1999, and Marpaung, 2003). In fact, the importance of developing the ability to think and the role of the teacher has long been proposed by Polya that to teach you how to think, teachers not only provide information but also putting themselves according to the conditions of students, and understand what is happening in the minds of students.

In line with this, in terms of learning each individual has advantages and disadvantages to absorb the lessons given. Each has a more convenient way of learning and learning is strongly influenced by the tendency of the workings of the brain is dominant. This is because that each individual is unique, meaning that every individual has the difference between the one with the other. The differences are manifold, ranging from physical differences, thought patterns, and ways to respond to or learn new things. For education, the failure to know how to learn will result in a learning process that saturate, it is difficult to get maximum results in the end achievement would be decreased.

In the world of education is now known various methods in order to meet the demands of the individual differences. In the developed countries and even the education system is created so that individuals can freely choose the pattern of education in accordance with his characteristics. Various measures can be undertaken by the school, such as by giving a good learning media, or by providing appropriate teaching methods for students.

STIFIn is one answer to it. STIFIn tests initiated by Poniman (2009) relies more scientifically the psychological analytical approach pioneered by Carl Gustav Jung, compiled with the theory of The Whole Brain Concept of Ned Herrmann and theory Tiune Brain. STIFIn test is a test that is done by scanning the tenth fingertips (take no more than one minute). Fingerprint carries information about the composition of the nervous system are then analyzed and linked to specific parts of the brain that acts as a dominant operating system and as well as a machine intelligence. In STIFIn, learned patterns of each machine intelligence modeled as follows: Sensing (S) good in memorizing, Thinking (T) is great at calculating, Intuiting (I) champion in creativity, Feeling (F) happy if discussion and Instinct (inclusive) learners versatile but need the peace to optimize brain function center (instinct) or better known as STIFIn through the fingerprint test. 
It is important for students to know that there is a potential or force on them in optimizing capabilities. So by knowing the dominant intelligence engine, students are more comfortable in the learning process. They can customize the learning patterns that they have learned through the results of these tests. Students who know the types of learning patterns they will adjust to learning in the classroom in order to be successful in learning and help students to become effective problem solver. Pattern or way of learning itself is one of the factors that affect how students learn mathematics. In addition, teachers will be more tolerate and put the maximum attention to the plurality of machine intelligence of each student.

This then becomes very important for teachers to analyze and determine the pattern of student learning that led to a lack of students' mathematical power. Because the type of machine intelligence STIFIn different causes in different ways of learning so that the mathematical power is also different. By directing students by machine intelligence, mathematical power is expected that students can be better. In addition, teachers can also find out students' mathematical power is lacking if each student has an intelligence engine STIFIn different so as to help teachers to meet the demands of a difference in the classroom and be able to carry out meaningful learning.

Based on the above, the question in this research is is "How can students' mathematical power if the terms of the test STIFIn?". So the purpose of this study is to analyze the students' mathematical power in terms of test STIFIn (Sensing (S), Thinking (T), Intuiting (I), Feeling (F), and instinct (In).

\section{METHOD}

This research has the characteristics of qualitative research that the researcher as a lead instrument, using qualitative methods, has a natural setting, descriptive, inductive data analysis, and more concerned with process than results. Therefore, the approach of this study is a qualitative approach. As the definition of Bogdan and Taylor in Moleong (2000: 3), a qualitative approach is a research procedure that produces data in the form of words written or spoken of people and behaviors that can be observed. The characteristics of qualitative research by Moleong (2000: 121) are: (1) has the natural background, (2) researchers as the main instrument, (3) using qualitative methods, (4) inductive data analysis, (5) the theory of basic , (6) is descriptive, (7) is more concerned with process than results, (8) the limits specified by the focus, (9) the specific criteria for the validity of the data, (10) the design of which is temporary, and (11) the results of research negotiated and agreed.

The research was conducted at SMAN 2 Serang, the reason why the researchers chose SMAN 2 Serang, because in this study one of the variables discussed is the test STIFIn, SMAN 2 Serang seemed appropriate, because it is one of the schools that do test STIFIn to students, for that researchers no longer need to perform tests STIFIn research on the subject because it is less effective in terms of cost given for tests STIFIn requires no small cost. When the study was conducted in the first semester of the academic year 2016/2017.

To determine the sample in this study the researchers used a sampling technique by purposive sampling were selected based on the goal to be achieved is to know the students' mathematical power in terms of test STIFIn. Subjects in this study were selected by considering the teacher's explanation about the type of dominant STIFIn owned by the students. The research subjects selected were three eleventh-grade students representing every type of STIFIn so that in total there were 15 students, then after being given a power of 
mathematical tests, chosen by each of the students who test scores of each type STIFIn dominant.

Aspects of the mathematical ability of students include; mathematical problem solving ability by using indicators Identify the elements that are known, asked, and the adequacy of the required elements; mathematical communication skills by using indicators Explaining ideas, situations, and mathematical relationships in writing; mathematical connection capabilities with the indicators Using mathematical mathematics in other areas of study or daily life (Sumarmo, 2010). Then to aspects of mathematical reasoning ability and mathematical representation of each used indicator of Ratnaningsih (2008), namely Checking the validity of the argument and Choose, apply and; changing representation to solve the problem.

To be able to give an objective assessment, the criteria scoring answers to questions test students' mathematical power ability by using the guidelines on Holistic Scoring Rubrics proposed by Cai, Lane \& Jakabcsin (1996) which was adapted.

Table 1: Criteria of Student's Answer Score

\begin{tabular}{cl}
\hline Score & \multicolumn{1}{c}{ Students Response } \\
\hline 0 & $\begin{array}{l}\text { No answer / reply does not correspond to the question / no } \\
\text { correct }\end{array}$ \\
1 & $\begin{array}{l}\text { Only some aspects of the statement is answered correctly } \\
\text { Answer incomplete (partial instructions followed) but contains } \\
\text { incorrect calculations }\end{array}$ \\
3 & $\begin{array}{l}\text { Almost all aspects of the question is answered correctly } \\
\text { All aspects of the questions were answered with complete / } \\
\text { clear and true }\end{array}$ \\
\hline
\end{tabular}

\section{RESULTS AND DISCUSSION}

\section{Results}

Mathematical power test given to students in grade eleven SMAN 2 Serang is a quadrilateral material, consisting of five questions representing each indicator of the ability of problem solving, reasoning, communication, connections and representation. The research subject was taken as a student selected by teachers to consider the dominant STIFIn intelligence engine owned. Then, after being given the power of mathematical tests, chosen by each of the students who score most dominant mathematical power. Based on the test results of mathematical power capabilities, the following list of names and scores of research subjects test results mathematical ability of students.

Table 2: Score of Mathematical Power Ability Test Results

\begin{tabular}{llll}
\hline No & Subjek & STIFIn & Score \\
\hline 1. & DNS & Thinking & 16 \\
2. & RA & Sensing & 16 \\
3. & MDP & Feeling & 11 \\
4. & LN & Intuiting & 9 \\
5. & SNS & Insting & 8 \\
\hline
\end{tabular}


Based on Table 2, it can be seen that subjects with type Thinking and Sensing has the highest score is 16 . Subsequently followed by subjects with type Feeling with a score of 11, the type Intuiting with a score of 9 and type of instinct with a score of 8 . The score for each ability in mathematical power capability: Problem Solving ability (PS), Reasoning (R), Communication $(\mathrm{Cm})$, Connections (Cn), Representation (Rp) may be seen in the following table.

Tabel 3: Score of Mathematical Power Ability per Item

\begin{tabular}{lllcccccc}
\hline \multirow{2}{*}{ No } & \multirow{2}{*}{ Subject } & \multirow{2}{*}{ STIFIn } & \multicolumn{5}{c}{ Mathematical Power Ability } & \multirow{2}{*}{ Score } \\
\cline { 5 - 7 } & & PS & R & Cm & Cn & Rp & Total \\
\hline 1 & DNS & Thinking & 2 & 4 & 4 & 4 & 2 & 16 \\
2 & RA & Sensing & 2 & 4 & 4 & 4 & 2 & 16 \\
3 & MDP & Feeling & 1 & 3 & 2 & 4 & 1 & 11 \\
4 & LN & Intuiting & 2 & 2 & 2 & 2 & 1 & 9 \\
5 & SNS & Insting & 1 & 2 & 2 & 3 & 0 & 8 \\
\hline
\end{tabular}

Based on Table 3. It can be seen that students with Thinking and Sensing types have the same score and the highest. Both do the calculations correctly and the steps are clear. It's just the matter of solving problems and questions about representation, the answer is incomplete (partial instructions followed) but contains incorrect calculations. The observation of the researcher at the time of the test, that students with types Thinking and Sensing very serious in doing the given problem, and to maximize the allotted time. So that both students are students who most recently collecting test questions and answers. When interviewed about the answers that are not answered correctly, the student with the type Sensing replied that he forgot the formula, thus making its calculations wrong. While type Thinking replied that she remembered with the formula, but she did not understand about the comparison contained in the problem solving and representation task.

\section{Discussion}

It was mentioned earlier that the mathematical aspects of the capability of the students in this study include the ability of mathematical problem solving, mathematical reasoning, mathematical communication, mathematical connection and mathematical representation. The items used in this study are as follows:

Items 1. (mathematical problem solving; Identify the elements that are known, asked, and the adequacy of the required elements)

"Ibu mempunyai selembar kain berbentuk persegi panjang dengan keliling 100m. Perbandingan ukuran panjang dan lebar kain tersebut adalah $3: 2$.

a. Unsur apa saja yang diperlukan untuk mencari luas kain ibu?

b. Bagaimana cara menentukan luas kain ibu?"

Items 2. (mathematical reasoning; Checking the validity of the argument)

"Jika sebuah jajargenjang memiliki luas $126 \mathrm{~cm}^{2}$ dan memiliki tinggi $9 \mathrm{~cm}$. Benarkah jajar genjang tersebut memiliki alas $14 \mathrm{~cm}$ ? Buktikanlah jawabanmu." 
Items 3. (mathematical communication; Explaining ideas, situations, and mathematical relationships in writing)

"Luas kebun berbentuk persegi panjang sama dengan luas kebun berbentuk persegi yang panjang sisinya $8 \mathrm{~m}$. jika lebar kebun yang berbentuk persegi panjang adalah $4 \mathrm{~m}$.

a. Nyatakanlah dalam bentuk gambar

b. Bagaimanakah cara menentukan panjang kebun yang berbentuk persegi panjang tersebut?

Items 4. (mathematical connection; Using mathematical mathematics in other areas of study or daily life)

"Seorang siswa memiliki buku gambar berukuran $0,4 \mathrm{~m}$ x $0,6 \mathrm{~m}$. Buku gambar itu akan digunakan untuk menggambar bingkai foto berukuran $5 \mathrm{~cm} \times 5 \mathrm{~cm}$. Bingkai foto tersebut tidak boleh saling berpotongan.

a. Bentuk bangun apakah buku gambar yang dimiliki oleh siswa?

b. Berbentuk bangun apakah bingkai foto yang akan digambar oleh siswa?

c. Berapa banyak bingkai foto yang akan digambar oleh siswa pada buku gambar?"

Items 5. (mathematical representation; changing representation to solve the problem)

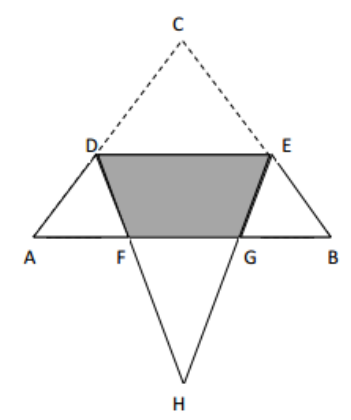

"Bagian atas $\triangle A B C$ dilipat ke arah atas pada bagian DE seperti tampak pada gambar di atas. $A B$ dan $D E$ sejajar dengan panjang berturut - turut $10 \mathrm{~cm}$ dan $8 \mathrm{~cm}$. Tinggi $\triangle A B C$ adalah 15 $\mathrm{cm}$ Perbandingan ukuran panjang $F G: A B=3: 5$ dan perbandingan tinggi $t A B C: t D A F=4: 1$. Bagaimanakah cara menentukan luas daerah yang diarsir?"

Based on research results, the student with the type Feeling, has a score under the type of Thinking and Sensing. Most of the students' answers Feeling types are only some aspects were answered correctly that in a matter of problem-solving abilities and representation, while the answer to the problem of communication incomplete (partial instructions followed) but contains incorrect calculations. The highest score is on a matter of connections, the answer is right but in a different way, he described the sketch book and a picture frame with a small scale so that it can find the number of picture frames that will be in the image of students in accordance with which he describes. When interviewed about the answer to the question, the student types Feeling said that the question of a matter can he understood, but he had difficulties in answering especially what steps should be done first, and he said most forgotten by the formula.

Then to students Intuting type and instinct to score each of 9 and 8 . Almost all the answers are less complete (some instructions followed) but contains incorrect calculations. Most of the responses of the type Intuiting and instinct is the answer to the point, so there is no systematic steps, although some of them the correct answers. When interviewed about the answer, the student with the type Intuiting replied that in general of all the questions he knew what was being asked, just confused answer because it already forget the material and formula, so some 
answers in the answer by guessing only. As for the students' instinct, when interviewed about the results of the answer is approximately the same as the type Intuiting answer, answered with a guess as to forget the formula and how. But for students with the type of instinct, the answer is almost every answer sheet made image first and then answer directly without using the formula.

Furthermore, researchers also interviewed teachers Guidance and Counseling (BK) in the school about the test results were reviewed based on the mathematical power STIFIn types of students. Based on information from the teacher BK, that's the type of Sensing and Thinking is consistent with any problems or issues related to the calculation, since both types of work by using the left brain. This is consistent with the theory of explanation Poniman (2012) who mapped the cerebral hemispheres, where each part of the brain has a special function that no other part. For the type of Thinking located in the left brain, and Sensing types are on the left limbic. Similarly, research conducted by Lutfiananda \& Rosyidi (2014) states that the type Sensing and Thinking more detail and sequentially in performing the troubleshooting steps and more planned in answering questions and its reasons are logical

As for the type of Feeling more students to use their feelings, according to BK teacher who is a trainer STIFIn, students with Feeling types are actually able to solve the problem but they are often affected by mood or feelings, so that test scores can change. Then for Intuiting type is the type of people who are creative, but sometimes creativity can come out of academia, so it's natural that mathematics scores obtained are smaller than the type in the left hemisphere. In accordance with the explanation Poniman (2012) that for the type of Intuiting are on the right brain and Feeling types are on the right limbic. Then for the last type is instinct which is at the midbrain. According to the results of interviews with teachers BK, the type of instinct is the type of person who versatile, in fact he was able to solve various problems, but the type of instinct can be said to be a follower, it will be a positive person if it follows a positive person, and that being negative if followed negative person. In accordance with the explanation Poniman (2012) that for the type of instinct to be in the midbrain. For students with the type of instinct selected as research subjects seem to be affected by the surrounding environment is negative, so that the results of tests done not in accordance with the expected potential of the type he had.

\section{CONCLUSION}

From the research and discussion above, it can be concluded that students with STIFIn types that are in the left hemisphere (Sensing and Thinking) higher than the power of mathematical STIFIn types that are in the right hemisphere (Intuiting and Feeling). As for the students' mathematical power capability with STIFIn types that are in the midbrain (instinct) were at the bottom among the other types.

STIFIn can serve as guidelines for teachers to understand the behavior of the students that although essentially as an individual, but have differences in ability, personality, and experience the environment (Rosita, 2013). Teachers are also expected to determine the learning method in accordance with the type of the students STIFIn. In addition, students who already know each machine intelligence can further optimize their ability and receive more focus in learning, especially mathematics. 


\section{REFERENCES}

Cai, J., Lane, S., \& Jakabcsin, M. S. (1996). The Role of Open-Ended Tasks and Holistic Scoring Rubrics: Assessing Students' Mathematical Reasoning and Communication. Communication in Mathematics, K-12 and Beyond, 137-145.

Djohar, M. S. (2003). Pendidikan Strategis, Alternatif untuk Pendidikan Masa Depan Menuju Masyarakat Madani. Bandung: Tarsito.

IMSTEP-JICA (1999). Monitoring Report on Current Practice on Mathematics and Science Teaching and Learning. Bandung: IMSTEP-JICA

Japar. (2015). Model Pembelajaran Berbasis Masalah Setting Kooperatif Untuk Meningkatkan Daya Matematis Dan Keterampilan Sosial. Journal of EST, 1 (1), 12-26.

Lutfiananda \& Rosyidi. (2014). Profil Pemecahan Masalah Open-Ended Siswa SMP dengan Tipe STJ dan NFJ dalam Kepribadian Myers-Briggs Type Indicators (MBTI) pada Materi Ukuran Pemusatan Data. Mathedunesa Jurnal Ilmiah Pendidikan Matematika, 3 (2).

Marpaung, Y. (2003). Perubahan Paradigma Pembelajaran Matematika di Sekolah. In Makalah. Disampaikan dalam Seminar Pendidikan Matematika di USD Yogyakarta, Yogyakarta (pp. 27-28).

Moleong, J. L. (2000). Metodologi Penelitian Kualitatif Edisi Revisi. Bandung: PT. Remaja Rosdakarya.

National Council of Teachers of Mathematics (2000). Principles and Standards for School Mathematics. Reston: NCTM.

Poniman, F. (2009). STIFIn personality mengenali mesin kecerdasan anda. Bekasi : PT. STIFIn fingerprint.

Poniman, F. (2012). Penjelasan Hasil Tes STIFIn Mengenali Cetak Biru Hidup Anda. Bekasi: PT STIFIn fingerprint.

Ratnaningsih, N. (2008). Berbagai Keterampilan Berpikir Matematik. Makalah Disajikan dalam Acara Seminar Pendidikan Matematika di Universitas Siliwangi Tasikmalaya pada Tanggal 8 Maret 2008. Tasikmalaya.

Rosita, C. D. (2013). Peranan Psikologi Pembelajaran Terhadap Peningkatan Kualitas Lingkungan Belajar Matematika. Infinity, 2 (2), 136-143

Sumarmo, U. (2010). Berfikir dan Disposisi Matematik: Apa, Mengapa, dan Bagaimana Dikembangkan pada Peserta Didik. Handout perkuliahan FPMIPA UPI. Bandung: Tidak diterbitkan

Suradi. (2006). Interaksi Siswa SMP dalam Pembelajaran Matematika Secara Kooperatif. Disertasi Program Pascasarjana Universitas Negeri Surabaya. Surabaya: Tidak diterbitkan. 